\title{
NATURAL OCCURRENCE OF NIVALENOL AND MYCOTOXIGENIC POTENTIAL OF FUSARIUM GRAMINEARUM STRAINS IN WHEAT AFFECTED BY HEAD BLIGHT IN ARGENTINA
}

\author{
V.E. Fernandez Pinto ${ }^{1 *}$; L.A. Terminiello² J.C. Basilico $^{3}$; A. Ritieni ${ }^{4}$
}

${ }^{1}$ Departamento de Química Orgánica, Facultad de Ciencias Exactas y Naturales, Universidad de Buenos Aires, Ciudad Universitaria, Buenos Aires, Argentina; ${ }^{2}$ Cátedra de Industrias Agrícolas de Lechería-Agroindustrias, Facultad de Ciencias Agrarias y Forestales Universidad Nacional de La Plata, La Plata, Buenos Aires, Argentina; ${ }^{3}$ Ingeniería en Alimentos, Facultad de Ingeniería Química, Universidad Nacional del Litoral, Sta. Fe, Argentina; ${ }^{4}$ Dipartamento di Scienza degli Alimenti, Università di Napoli "Federico II", Portici, Napoli, Italia.

Submitted: July 11, 2007; Returned to authors for corrections: August 15, 2007; Approved: November 16, 2007.

\begin{abstract}
The principal agents of Fusarium head blight in the main cropping area of Argentina were investigated in heavily infected samples. The ability of the isolates to produce trichothecenes was determined by GC and HPLC. Fusarium graminearum was the predominant species and of 33 isolates, 10 produced deoxinivalenol (DON) (0.1-29 $\left.\mathrm{mg} \mathrm{kg}^{-1}\right), 13$ produced both deoxinivalenol (1.0- $\left.708 \mathrm{mg} \mathrm{kg}^{-1}\right)$ and nivalenol $\left(0.1-6.2 \mathrm{mg} \mathrm{kg}^{-1}\right), 12$ produced 3-acetyldeoxinivalenol ( $\left.0.1-14 \mathrm{mg} \mathrm{kg}^{-1}\right), 13$ produced 15 -acetyldeoxinivalenol $\left(0.1-1.9 \mathrm{mg} \mathrm{kg}^{-1}\right), 10$ produced Fusarenone $X\left(0.1-2.4 \mathrm{mg} \mathrm{kg}^{-1}\right)$ and 7 produced zearalenone $\left(0.1-0.6 \mathrm{mg} \mathrm{kg}^{-1}\right)$. These results suggest that $F$. graminearum strains isolated from the wheat growing regions in Argentina belong to DON chemotype. Although some strains produced both deoxinivalenol and nivalenol, nivalenol was produced in lower levels. The natural occurrence of nivalenol in wheat affected by head-blight collected in the main production area during two years (2001-2002) was also determined. From 19 samples 13 were contaminated with deoxinivalenol in a range of 0.3 to $70 \mathrm{mg} \mathrm{kg}^{-1}$ and 2 samples with both deoxinivalenol $(7.5$ and $6.7 \mathrm{mg}$ $\left.\mathrm{kg}^{-1}\right)$ and nivalenol $\left(0.05\right.$ and $\left.0.1 \mathrm{mg} \mathrm{kg}^{-1}\right)$, respectively. This is the first report of natural occurrence of nivalenol in wheat cultivate in Argentina.
\end{abstract}

Key words: Fusarium, nivalenol, toxicogenic potential, trichotecenes.

\section{INTRODUCTION}

Wheat is one of the most important cereal crops in Argentina both for local consumption and as an export commodity, with yields over 12.000.000 tons (1). The cultivated area of 6.000.000 ha is distributed according to agrometeorological conditions into five zones, with a main production area on the Buenos Aires province (Zones IIS, IV and VS), East of La Pampa province (Zone VS) and South of Santa Fe province (Zone IIN). This extended area presents very different conditions of temperature and humidity. The incidence of toxigenic Fusarium spp. and their toxins overall this wide cultivated area has been scarcely studied. F. graminearum Schwabe [teleomorph Gibberella zeae (Schw.) Petch] is the most common causal agent of Fusarium head blight (FHB) in many parts of the world. Recent outbreaks had been reported in USA, Asia, Canada, Europe and South America. This destructive disease affects wheat, barley and other small grains in temperate and semitropical areas. The disease has the capacity to destroy a potentially high- yielding crop within a few weeks of harvest, causing economic looses due to reduced seed quality. Additionally, infected grains may contain significant levels of mycotoxins like trichothecenes and zearalenone. Trichothecenes toxins are sesquiterpenoids that are potent inhibitors of eucaryotic protein biosynthesis. Adverse

Departamento de Química Orgánica. Facultad de Ciencias Exactas y Naturales. Universidad de Buenos Aires. Ciudad Universitaria. Pabellón II. $3^{\text {er }}$ Piso (1428), Buenos Aires, Argentina. Tel./Fax: +54 11 4576-3346. E-mail: virginia@qo.fcen.uba.ar 
effects of the toxins in animals are food refusal, diarrhoea, emesis, alimentary haemorrhaging, contact dermatitis and immunosuppression. Zearalenone is an estrogenic mycotoxin (11). Some earlier works have shown that $F$. graminearum was the main occurring species and deoxinivalenol (DON) was the main toxin contaminant detected in wheat and wheat-products in Argentina (10,18,19,20). Two main chemotypes were reported in G. zea from rice in Japan: the "NIV chemotype" which produces nivalenol (NIV) and Fusarenone X (Fus-X) and the "DON Chemotype" which produces deoxinivalenol (DON) and its acetylated forms (12). Differences in the geographical distribution of DON and NIV chemotypes of $F$. gramineraum have been reported. Only the DON chemotype has been found in the United States and Canada (16), while both chemotypes were isolated in Japan (26), Italy (14), South Africa (23), and Australia (2). Successively, Sugiura et al. (22) demonstrated that some G. zeae isolated from rice stubble in Japan produced both NIV and DON. This capability was also confirmed in some strains in Hungary (24) and in strains isolated from maize and wheat in Nepal (6). The ability of Argentinean Fusarium isolates to produce trichothecenes is controversial and the pattern of micotoxin production is not already well defined. Faifer et al. (8) reported that $F$. graminearum isolated from wheat in Argentina produced DON, 15- acetyldeoxinivalenol (15AcDON), 3acetyldeoxinivalenol (3AcDON) and zearalenone (ZEA) while Ramirez et al (20) found only DON and 3-AcDON producers. On the other hand, Lori (15) studied the capability of $76 \mathrm{~F}$. graminearum strains isolated from Argentinean wheat and 56\% produced DON, 3 AcDON, $10 \%$ NIV, FUS-X and $34 \%$ both DON and NIV. All those studies were carried out in crops heavily affected by FHB.

The purposes of this study were to determine:

a) the pattern of trichothecene production by the isolates of the principal FHB agents

b) the presence of both NIV and DON producing strains

c) the natural occurrence of NIV, in Argentinean wheat affected by FHB

\section{MATERIALS AND METHODS}

\section{Wheat samples}

Nineteen wheat samples affected by head blight were collected from four regions in the major wheat production area in Argentina, 5 in the 2000- 2001 harvest and 14 in the 2001-2002 one. In both harvests the meteorological conditions favour the infection. The regions were: Region II North (IIN) and Region II South (IIS) (North of Buenos Aires province), Region IV (South East of Buenos Aires province) and Region V (South West of Buenos Aires and La Pampa province). Regions IIN and IIS have a temperate humid climate while Regions IV and V have a more continental semiarid one. Samples were also collected from farms in 15 districts of Bs. As. and La Pampa provinces. At least
$0.5 \mathrm{~kg}$ was collected per sample, selected from heads with spikelets with visible symptoms of FHB. All samples were from locally grown cultivars.

\section{Mycological analyses}

For the isolation of the internal micoflora, 100 wheat kernels of each sample were surface disinfected in a $2 \%$ aqueous solution of commercial sodium hypochlorite for 1 minute and rinsed twice with sterile distilled water. The kernels were placed, 10 kernels per plate, on potato dextrose agar (PDA) with $2 \%$ of pentachloro nitrobenzene (PCNB) plates and incubated for 5 days a $28^{\circ} \mathrm{C}$ under fluorescent and black light lamps (2700 lux; $12 \mathrm{~h}$ photoperiod) to stimulate conidial formation and the percentage of infected kernels was calculated. Representative cultures of the species isolated were grown from single conidia for 7 days on petri dishes with carnation leaves agar (CLA) and with potato dextrose agar (PDA) and incubated a $28^{\circ} \mathrm{C}$ under fluorescent light. The identification of colonies of Fusarium species was made according to the criteria and synoptic keys of Leslie and Summerell (13)

\section{Toxin analysis \\ Sample analysis}

A subsample of $25 \mathrm{~g}$ of wheat was milled at $2500 \mathrm{rpm}$ in a commercial grinder. The extraction of deoxynivalenol (DON), nivalenol (NIV), was done with $125 \mathrm{ml}$ of acetonitrile: ethyl acetate: water (50:41:9) as extraction solvent per 1 hour at 300 $\mathrm{rpm}$. The clean-up was made with a column packed with charcoal: alumina: celite (0.7:0.5:0.3) (19); and the extract was dried in a rotary evaporator. The dry residue was re-dissolved in $500 \mathrm{ml}$ ethyl acetate: metanol (95:5) and transferred to a vial.

\section{Evaluation of toxicogenic capacity of Fusarium isolates}

To test for trichothecenes and zearalenone production, Fusarium isolates were placed in duplicate on $25 \mathrm{~g}$ of sterilized rice in $500 \mathrm{ml}$ Erlenmeyer flasks. The rice was added with $15 \mathrm{ml}$ of sterile distilled water before sterilization by autoclaving al $121^{\circ} \mathrm{C}$ for $15 \mathrm{~min}$. Each flask was inoculated with a suspension containing $10^{6}$ conidia $\mathrm{ml}^{-1}$. The conidial suspension was performed by adding $5,0 \mathrm{ml}$ of sterile distilled water to a slant of a 7day culture at $28^{\circ} \mathrm{C}$ on PDA and gently scraping the agar surface with a wire loop to give a turbid suspension.

\section{Toxin extraction}

DON, NIV, 15AcDON, 3AcDON, FUSX, and ZEA were extracted with acetonitrile: ethyl acetate: water (50: 41:9) as extraction solvent, and the clean up was made with a column packed with charcoal: alumina: celite (0.7: 0.5: 0.3) as was previously described (19).

Standards of DON, NIV, 15AcDON, 3AcDON, FUSX, and ZEA were purchased from SIGMA chemical Company (St. Louis, MO, USA). 


\section{Toxin detection}

Toxins detection for both samples and isolates production was made by gas liquid chromatography (CGL) and the NIV presence was confirmed in all cases by HPLC.

DON, 3-AcDON, 15 AcDON, FUSX and ZEA were also confirmed by TLC (15)

\section{CGL}

Trichothecenes and ZEA were detected and quantified by gas liquid chromatography with $\mathrm{Ni}^{63}$ electron capture detection Shimadzu Model GC17, equipped with split/splitless injector and fitted with a RX-5MS capillary column ( $25 \mathrm{~m} \times 0,2 \mathrm{~mm}$ i.d.). The injector temperature was $250^{\circ} \mathrm{C}$ and the detector one $300^{\circ} \mathrm{C}$. Separation was achieved with a temperature program consisting of $1 \mathrm{~min}$ at $80^{\circ} \mathrm{C}$, then increase $80^{\circ} \mathrm{C}-140^{\circ} \mathrm{C}$ at $30^{\circ} \mathrm{C}$ per min, followed by $140^{\circ} \mathrm{C}-280^{\circ} \mathrm{C}$ at $5^{\circ} \mathrm{C}$ per min. Both the carrier and auxiliary gas were nitrogen. The derivatization was carried out with heptafluorbutyric anhydride with the method reported by Croteau et al. (4). The detection limit for DON and its acetyl derivatives was $20 \mu \mathrm{g} \mathrm{kg}^{-1}$ and for NIV, FUS and ZEA $50 \mu \mathrm{g} \mathrm{kg}^{-1}$ respectively

\section{HPLC}

NIV was confirmed with Shimadzu HPLC ( 2 pumps LC-10 ADvp, 1 DAD SPD- M10Avp, 1 System controller SCL-10 Avp) with precolumn Phenomenex Widepore C18 (ODS) $(4 \times 3 \mathrm{~mm})$ and column Phenomenex Jupiter 5u C18 (300A, 20x 4,6 mm). Each analysis was done with a $20 \mathrm{ul} \mathrm{loop}$, water (A) + acetonitrile (B) as eluent solvents (gradient: 0 min 10\% B, 10min 100\% B, 13 $\min 100 \% \mathrm{~B}, 16 \min 10 \% \mathrm{~B}, 20 \mathrm{~min} 10 \% \mathrm{~B}$ ), total flow $1 \mathrm{ml}$ per min at wavelength: $219 \mathrm{~nm}$. The detection limit was $50 \mu \mathrm{g} \mathrm{kg}^{-1}$.

\section{RESULTS}

The percentage of infected kernels in the samples is illustrated in Table 1. In 13 of the 19 samples the infection was of $100 \%$. In the other samples the level of infection was always high (69 to 95\%). Fusarium graminearum was found as the main occurring species and it was found in 17 samples in levels from 4 to $88 \%$. Fusarium poae and $F$. verticillioides were also rarely encountered (less of $2 \%$ ).

All the samples were assayed from the presence of DON and NIV. The results were presented in Table 1, where it is also shown the geographical origin of the samples.

Fifteen of the 19 samples were contaminated with DON and the levels ranged from 0.3 to $70 \mathrm{mg} \mathrm{kg}^{-1}$. In this study 2 samples (Arrecifes from North of Buenos Aires province and Conhelo from La Pampa province) were contaminated with DON (7.5 and $\left.6.7 \mathrm{mg} \mathrm{kg}^{-1}\right)$ and NIV (0.05 and $\left.0.1 \mathrm{mg} \mathrm{kg}^{-1}\right)$ respectively. From the samples of wheat most heavily contaminated were isolated 33 strains of $F$. graminearum and their toxicogenic potential was determined in autoclaved rice.

Table 1. Natural occurrence of DON and NIV in Argentinean wheat affected by head blight.

\begin{tabular}{|c|c|c|c|c|c|}
\hline Zone & Sample & Infected. kernels \% & F. graminearum\% & DON mg kg ${ }^{-1}$ & NIV $m g ~ k g^{-1}$ \\
\hline IIN & 13-Pergamino & 100 & 50 & 7.8 & $\mathrm{ND}$ \\
\hline \multirow{6}{*}{ IIS } & 14-San Pedro & 100 & 82 & 70 & $\mathrm{ND}$ \\
\hline & 1-Arrecifes & 100 & 74 & 7.5 & 0.05 \\
\hline & 9- Salto & 100 & 88 & 16 & $\mathrm{ND}$ \\
\hline & 15-Villegas & 100 & 40 & 3.0 & ND \\
\hline & 19- Lincoln & 100 & 6 & 3.3 & $\mathrm{ND}$ \\
\hline & 10 -Saladillo & 100 & 85 & 14 & $\mathrm{ND}$ \\
\hline \multirow{5}{*}{ IV } & 2-Olavarria & 100 & - & - & $\mathrm{ND}$ \\
\hline & 3-Olavarria & 100 & 21 & 1.3 & $\mathrm{ND}$ \\
\hline & 4- Olavarria & 83 & - & 0.8 & ND \\
\hline & 7- Gral.Pueyrredon & 100 & 12 & 0.3 & ND \\
\hline & 11- Gral. Pueyrredon & 100 & 4 & 0.4 & ND \\
\hline \multirow{7}{*}{$\mathbf{V}$} & 5- Cnel Suarez & 85 & 39 & 5.4 & ND \\
\hline & 8-Conhelo & 95 & 67 & 6.7 & 0.1 \\
\hline & 12-Conhelo & 100 & 43 & 5.8 & ND \\
\hline & 6- Mt. Nievas & 100 & 39 & 5.8 & $\mathrm{ND}$ \\
\hline & 16- Luiggi & 86 & 4 & ND & ND \\
\hline & 17- Winifreda & 69 & 7 & $\mathrm{ND}$ & $\mathrm{ND}$ \\
\hline & 18-Castex & 79 & 6 & ND & ND \\
\hline
\end{tabular}


Concentration of trichothecenes and zearalenone produced are illustrated in Table 2.

In this study, 10 strains produced DON ranging between 0.1 and $29 \mathrm{mg} \mathrm{kg}^{-1}$. Of these strains 3 produced also $3 \mathrm{AcDON}$ ranging between 0.7 and $3.0 \mathrm{mg} \mathrm{kg}^{-1}$ and 4 produced $15 \mathrm{AcDON}$ ranging between 0.1 and $0.9 \mathrm{mg} \mathrm{kg}^{-1}$. The results also demonstrated the production of both DON (ranging between 1.0 and $708 \mathrm{mg} \mathrm{kg}^{-1}$ ) and NIV (ranging between 0.1 and $6.2 \mathrm{mg}$ $\mathrm{kg}^{-1}$ ) by 13 of $33 \mathrm{~F}$. graminearum strains tested. In DON and NIV producers, 9 strains produced FUS X (up to $2.4 \mathrm{mg} \mathrm{kg}^{-1}$ ), 8 produced $3 \mathrm{AcDON}$ (up to $14 \mathrm{mg} \mathrm{kg}^{-1}$ ) and 9 produced $15 \mathrm{AcDON}$ (up to $1.9 \mathrm{mg} \mathrm{kg}^{-1}$ ). Of these, 5 strains produced $3 \mathrm{AcDON}$ and 15 AcDON simultaneously. Only one strain produced FUS X

Table 2. Production of trichothecenes and zearalenone by $F$. graminearum isolates $\left(\mathrm{mg} \mathrm{kg}^{-1}\right)$.

\begin{tabular}{ccccccccc}
\hline Strain $\mathrm{N}^{\circ}$ & Sample & Region & NIV & FUSX & DON & 3DON & 15ADON & ZEA \\
\hline 4620 & 13 & IIN & ND & ND & 25 & ND & ND & ND \\
4614 & 10 & IIS & ND & ND & 19 & 0.9 & ND & ND \\
4601 & 1 & IIS & ND & ND & 29 & 0.7 & 0.1 & ND \\
4602 & 1 & IIS & ND & ND & 8.3 & 3.0 & 0.9 & ND \\
4604 & 1 & IIS & ND & ND & 10 & ND & ND & ND \\
4622 & 14 & IIS & ND & ND & 2.5 & ND & 0.2 & ND \\
4626 & 14 & IIS & ND & ND & 25 & ND & 0.1 & ND \\
4629 & 15 & IIS & ND & ND & 16 & ND & ND & ND \\
4632 & 9 & IIS & ND & ND & 6.0 & ND & ND & 0.1 \\
4617 & 13 & IIN & ND & ND & 0.1 & ND & ND & \\
4619 & 13 & IIN & 0.8 & 2.4 & 120 & 2.9 & 0.3 & 0.1 \\
4615 & 10 & IIS & 1.5 & 2 & 95 & ND & 1.8 & ND \\
4616 & 10 & IIS & 0.4 & 0.1 & 38 & 2 & 0.2 & 0.6 \\
4600 & 1 & IIS & 6.2 & 0.7 & 708 & 14 & ND & ND \\
4603 & 1 & IIS & 0.2 & ND & 11 & ND & ND & ND \\
4623 & 14 & IIS & 0.1 & ND & 1.0 & 0.3 & ND & 0.1 \\
4634 & 9 & IIS & 1.1 & ND & 14 & 1.0 & 0.3 & ND \\
4635 & 9 & IIS & 2.1 & ND & 21 & ND & 1.9 & 0.1 \\
4636 & 9 & IIS & 0.6 & 0.1 & 37 & 0.3 & 0.1 & ND \\
4637 & 9 & IIS & 0.2 & 0.1 & 98 & 0.1 & ND & ND \\
4638 & 9 & IIS & 2.2 & 0.1 & 17 & ND & 0.7 & 0.1 \\
4640 & 15 & IIS & 0.5 & 0.1 & 8.5 & ND & 0.3 & ND \\
4606 & 7 & IV & 0.2 & 0.1 & 58 & 1.0 & 0.4 & 0.4 \\
4609 & 8 & VS & ND & 0.2 & 20 & 4.1 & ND & ND \\
4618 & 13 & IIN & ND & ND & ND & ND & ND & ND \\
4624 & 14 & IIS & ND & ND & ND & ND & ND & ND \\
4625 & 14 & IIS & ND & ND & ND & ND & ND & ND \\
4627 & 14 & IIS & ND & ND & ND & ND & ND & ND \\
4628 & 14 & IIS & ND & ND & ND & ND & ND & ND \\
4631 & 9 & IIS & ND & ND & ND & ND & ND & ND \\
4633 & 9 & IIS & ND & ND & ND & ND & ND & ND \\
4605 & 7 & IV & ND & ND & ND & ND & ND & ND \\
\hline & & & & & & & & \\
\hline
\end{tabular}

$\left(0.2 \mathrm{mg} \mathrm{kg}^{-1}\right)$, DON $\left(20 \mathrm{mg} \mathrm{kg}^{-1}\right)$ and 3 AcDON (4.1 $\left.\mathrm{mg} \mathrm{kg}^{-1}\right)$. Zearalenone was produced by 7 strains in low amounts, ranging between 0.1 and $0.6 \mathrm{mg} \mathrm{kg}^{-1}$ and no exclusive relationship could be observed between ZEA production and the DON and NIV production. Finally, we did not detect trichothecene production from eight strains.

\section{DISCUSSION}

These results agree with other reports carried out in Argentina where $F$. graminearum proved to be the main toxigenic Fusarium species $(10,15,20)$. All the samples collected in the zones IIN and IIS are $100 \%$ infected. On the contrary, zone V can be considered less contaminated because $71.42 \%$ of samples don't reach $100 \%$ of infection. In fact, F. graminearum is the most frequent fungi in the zone IIN and IIS while the percentages are lower in the zones IV and V.

The levels of toxin contamination found in samples in this study are similar to those reported earlier in heavily infected wheat in Argentina $(10,19)$. This is the first report of the natural occurrence of NIV in wheat cultivated in Argentina. DON and NIV are very similar in their chemical structure, but differ markedly in their toxicological properties with NIV considered more mycotoxic than DON (25). Therefore the presence of NIV in Argentinean wheat may have a significant impact on the food safety aspects because its presence can synergize the toxicity of DON. By this study and other reports $(5,10,19)$ Argentina prove to have a high risk of DON wheat contamination due to the high incidence of FHB, particularly in the area with temperate humid climate. This risk seems also to be present in South of Brazil (9) and Uruguay (18).

Overall, the DON production by strains proved to be higher that NIV. All the data analyzed in this study support the fact that the variation among the toxigenic potential of $F$. graminerum strains isolated from Argentinean wheat is quite complex and may contribute to a wide range of mycotoxin content in this cereal. The introduction of novel FHB chemotypes via global trade in agricultural products should be assessed because could have the potential to exacerbate FHB problem (17). In particular the relative frequency of DON and NIV is of concern because recent reports suggest that strains of 
the $F$. graminearum complex that produce NIV may be more aggressive towards corn but less aggressive to wheat than DON producing strains. These results indicate that there may be important consequences for the fitness and aggressiveness of FHB pathogens of different chemotype on particular hosts $(3,7,11)$. Further studies will be necessary in order to characterize the genetic diversity, chemotype and virulence of $F$. graminearum populations from Argentina, a country where this species is widespread and wheat is cultivated under different agro-meteorological conditions.

\section{RESUMO}

\section{Ocorrência natural de nivalenol e potencial micotoxigênico de cepas de Fusarium graminearum em trigo afetado por giberela na Argentina}

O principal causador de giberela no trigo na Argentina e sua capacidade de produzir tricotecenos foram estudados por GC e HPLC em amostras altamente infectadas. A espécie predominante foi Fusarium graminearum, sendo que de um total de 33 isolados, 10 produziram deoxinivalenol $(0,1-29 \mathrm{mg}$ $\left.\mathrm{kg}^{-1}\right), 13$ produziram deoxinivalenol $\left(1,0-708 \mathrm{mg} \mathrm{kg}^{-1}\right)$ e nivalenol $\left(0,1-6,2 \mathrm{mg} \mathrm{kg}^{-1}\right), 12$ produziram 3-acetildeoxinivalenol (0,1-14 $\left.\mathrm{mg} \mathrm{kg}^{-1}\right), 13$ produziram 15 -acetildeoxinivalenol $(0,1-1,9 \mathrm{mg} \mathrm{kg}$ $\left.{ }^{1}\right), 10$ produziram fusarenona $X\left(0,1-2,4 \mathrm{mg} \mathrm{kg}^{-1}\right) \mathrm{e} 7$ produziram zearalenona $\left(0,1-0,6 \mathrm{mg} \mathrm{kg}^{-1}\right)$. Esses resultados sugerem que as cepas de $F$. graminearum isoladas de trigo cultivado na Argentina pertencem ao quimiotipo DON. Embora algumas cepas tenham produzido tanto DON quanto NIV, NIV foi produzido em quantidade inferior ao DON. A ocorrência natural de nivalenol em trigo afetado pela giberela coletado na principal área de produção durante dois anos (2001-2002) foi também determinada. De 19 amostras, 13 estavam contaminadas com deoxinivalenol na faixa de 0,3 a $70 \mathrm{mg} \mathrm{kg}^{-1} \mathrm{e} 2$ amostras continham tanto deoxinivalenol $\left(7,5\right.$ e $\left.6,7 \mathrm{mg} \mathrm{kg}^{-1}\right)$ quanto nivalenol $(0,05 \mathrm{e}$ $\left.0,1 \mathrm{mg} \mathrm{kg}^{-1}\right)$, respectivamente. Esse é o primeiro relato da ocorrência de nivalenol em trigo cultivado na Argentina.

Palavras-chave: Fusarium, nivalenol, potencial toxicogênico, tricotecenos.

\section{REFERENCES}

1. Argentine Wheat (2005). Institutional Quality Report. http:/ www.trigo argentino.com.ar

2. Blaney, B.J.; Dodman, R.L. (1988). Production of the mycotoxins zearalenone, deoxynivalenol and nivalenol by isolates of Fusarium graminearum Groups 1 and 2 from cereals in Queensland. Aust. J. Agric. Res., 39, 21-29.

3. Carter, J.P.; Rezanoor, H.N.; Holden, D.; Desjardins, A.E.; Plattner, R.D.; Nicholson, P. (2002). Variation in pathogenicity associated with the genetic diversity of Fusarium graminearum. Eur. J. Plant Pathol., 108, 573-583
4. Croteau, S.; Prelusky, D.; Trenholm, H. (1994). Analysis of trichothecenes mycotoxins by CG with ECD. J. Agric. Food Chem., 42, 928-933.

5. Dalcero, A.; Torres, A.; Etcheverry, M.; Chulze, S.; Varsavsky, E. (1997). Occurrence of deoxynivalenol and Fusarium graminearum in Argentinian wheat. Food Addit. Contam., 14, 11-14.

6. Desjardins, A.E.; Manandhar, G.; Plattner, R.D.; Maragos, C.M.; Shrestha, K.Mc.; Cormick, S.P. (2000). Occurrence of Fusarium species and mycotoxins in Nepalese maize and wheat and the effect of traditional processing methods on mycotoxins levels. J. Agric. Food Chem., 48, 1377-1388.

7. Desjardins, A.E.; Jarosz, A.M.; Plattner, R.D.; Alexander, N.J.; Brown, D.W.; Jurgenson, J.E. (2004). Patterns of trichothecene production, genetic variability, and virulence to wheat of Fusarium graminearum from smallholder farms in Nepal. J. Agric. Food Chem., 52, 63416346.

8. Faifer, G.C.; De Miguel, M.S.; Godoy, H.M. (1990). Patterns of mycotoxin production by Fusarium graminearum isolated from Argentine wheat. Mycopathologia, 109, 165-170.

9. Furlong, E.B.; Soares, L.M.V.; Lasca, C.C.; Kohara, E.Y. (1995). Mycotoxins and fungi in wheat harvested during 1990 in test plots in the state of Sao Paulo, Brazil. Mycopathologia, 131, 185-190.

10. González, H.H.L.; Pacin, A.; Resnik, S.L.; Martínez, E.J. (1996). Deoxynivalenol and contaminant mycoflora in freshly harvested Argentinean wheat in 1993. Mycopathologia, 135, 129-134.

11. Goswami, R.S.; Kistler, C. (2004). Heading for disaster: Fusarium graminearum on cereal crops. Mol. Plant Pathol., 5, 515-525.

12. Ichinoe, M.; Kurata, H.; Sugiura, Y.; Ueno, Y. (1983). Chemotaxonomy of Gibberella zea with special reference to production of trichothecenes and zearalenone. Appl. Environ. Microbiol., 46, 1364-1369.

13. Leslie, J.F.; Summerell, B.A. (2006). The Fusarium lab manual. Blackwell, Ames.

14. Logrieco, A.; Bottalico, A.; Altomare, C. (1988). Chemotaxonomic observations on zearalenone and trichothecene production by Gibberella zeae from cereals in southern Italy. Mycologia, 80, 892895.

15. Lori, G.; Carranza, M.; Violante, A.; Rizzo, I.; Alippi, H. (1992). Fusarium ssp. En trigo, capacidad toxicogénica y quimiotaxonomía de las cepas aisladas en Argentina. Agronomie, 12, 459-467.

16. Miller, J.D.; Taylor, A.; Greenhalgh, R. (1983). Production of deoxynivalenol and related compounds in liquid culture by Fusarium graminearum. Can. J. Microbiol., 29, 1171-1178.

17. O'Donnell, K.; Ward, T.J.; Geiser, D.M.; Kistler, H.C.; Aoki, T. (2004). Genealogical concordance between the mating type locus and seven other nuclear genes supports formal recognition of nine phylogenetically distinct species within the Fusarium graminearum clade. Fungal Genet. Biol., 41, 600-623.

18. Piñeiro, M.; Dawson, R.; Costarrica, M.L. (1996). Monitoring program for mycotoxin contamination in Uruguayan food and feeds. Nat. Toxins, 4, 242-245

19. Quiroga, N.; Resnik, S.L.; Pacin, A.; Martínez, E.; Pagano, A.; Riccobene, I.; Neira, S. (1995). Natural occurrence of trichothecenes and zearalenone in Argentinean wheat. Food Control, 6, 201-204

20. Ramirez, M.L.; Reynoso, M.M.; Farnocchi, M.C.; Chulze, S.; (2006). Vegetative Compatibility and mycotoxin chemotypes among Fusarium graminerum (Gibberella zeae) isolates from wheat in Argentina. Eur. J. Plant Pathol., 115, 139-148.

21. Rizzo, I.; Lori, G.; Vedoya, G.; Carranza, M.; Haidukowski, M.; Varsavsky, E.; Frade, H.; Chiale, C.; Alippi, H. (1997). Sanitary factors and mycotoxin contamination in the argentinean wheat crop 1993-94. Mycotoxin Res., 13, 67- 71.

22. Sugiura, Y.; Watanabe, Y.; Tanaka, T.; Yamammota, S.; Ueno, Y. (1990). Occurrence of Gibberella zeae strains that produce both 
nivalenol and deoxininalenol. Appl. Environ. Microbiol., 56, 30473051

23. Sydenham, E.W.; Marasas, W.F.O.; Thiel, P.G.; Shephard, G.S.; Nieuwenhuis, J.J. (1991). Production of mycotoxins by selected Fusarium graminearum and F. crookwellense isolates. Food Addit. Contam., 8, 31-41.

24. Szecsi, A.; Bartok, T.; Varga, M.; Magyar, D.; Mesterhazy, A. (2005). determination of trichothecene chemotypes of Fusarium graminearum strains isolated in Hungary. J. Phytopathology, 153 (8), 445-448.

25. Ueno, Y. (1983). General Toxicology. In: Trichothecenes. Chemical, biological and toxicological aspects. Copublished by Kodansha Ltd. and Elsevier Science Publishers, Tokyo Japón.

26. Yoshizawa, T.; Jin, Y.Z. (1995). Natural occurrence of acetylated derivatives of deoxynivalenol and nivalenol in wheat and barley in Japan. Food Addit. Contam., 12, 689-694. 